Annals of Warsaw University of Life Sciences - SGGW

Land Reclamation No 49 (1), 2017: 15-27

(Ann. Warsaw Univ. Life Sci. - SGGW, Land Reclam. 49 (1), 2017)

\title{
Areal variability of the mineral soil cover in a reclaimed soda waste dumping site
}

\author{
SŁAWOMIR KLATKA ${ }^{1}$, EWELINA ZAJĄC ${ }^{1}$, JAN ZARZYCKI ${ }^{2}$ \\ ${ }^{1}$ Department of Land Reclamation and Environmental Development \\ ${ }^{2}$ Department of Ecology, Climatology and Air Protection \\ University of Agriculture in Krakow
}

\begin{abstract}
Areal variability of the mineral soil cover in a reclaimed soda waste dumping site. This paper provides an analysis of the areal variability of the thickness and selected physical and chemical properties of the mineral cover formed in the process of settling ponds reclamation at the former Krakow Soda Plant "Solvay". The topsoil is intended to provide a substrate for plants, therefore, its quality is the main determinant of the development for herbaceous and woody vegetation. Areal variability of the topsoil parameters was determined by kriging. In the context of the envisaged direction of management of the settling ponds, the analysis showed that electrical conductivity, thickness of the soil cover and the sand fraction content have potentially the highest impact on the diversification of vegetation. Understanding the spatial variability of the soil cover parameters, that are essential for vegetation, may contribute to increasing the efficiency of biological reclamation and also to cost reduction. Precise selection of the areas unsuitable for plant growth makes it possible to improve soil parameters on limited areas similarly as in the precision agriculture.
\end{abstract}

Key words: soda waste dumps, reclamation, soil cover, kriging

\section{INTRODUCTION}

Applying mineral soil cover is a method for reclaiming noxious waste dumping sites handling waste of various origins
(Gworek et al. 2004). The method consists in covering the site with an appropriately designed mineral cover. Such a cover system preferably comprises protective layers and is designed to prevent, first of all, the penetration of rainwater into the dumping site and the escape of substances which are harmful to the neighborhood, such as dust, gas or effluents. Covering the dumping site with the correctly designed mineral cap will also enable the introduction of vegetation onto its surface (Wysokiński 2009, Siuta 2014). The vegetation has a protective role in addition to being the essential component of natural compensation of the damage inflicted on the environment and the measures intended to restore natural balance.

An example of a waste dumping site that has been reclaimed by an application of a surface mineral cover is the one handling the chemical waste generated by the former Krakow Soda Plant "Solvay" (KSP "Solvay"). The soda plant manufactured mainly crude, calcined and caustic sodas, generating an immense volume of waste collected 
in ground tanks (settling ponds). The soda waste was composed mainly of calcium carbonate in the form of fine crystals, suspended in a water solution of calcium chloride (Pałka and Sanecki 1992). It had a high $\mathrm{pH}$ value and high salinity (Boroń et al. 2000, Zając et al. 2007, Boroń et al. 2016). Operated since 1930s, the KSP "Solvay" waste dumping site had generated many problems, including the outflow of high-salt effluents and escape of dust from the dryingout waste material. Consequently, KSP "Solvay" was closed down. In the years 1989-1995, the dumping site was reclaimed: levees were arranged between the settling ponds, the escarpments were reinforced, a mineral soil cover was applied, the area was leveled and, after providing the soil with mineral fertilizers, it was sown with a mixture of grass and legumes plant seeds (Małecki 1997, Zając and Zarzycki 2012). At present, the reclaimed settling ponds are covered by herbage vegetation and patches of pioneering species of trees (Zając and Zarzycki 2012, Zając et al. 2016). According to the local zoning plan, the reclaimed settling pond complex is intended to accommodate green area and sports-and-recreation facilities (Resolution LVIII/777/12).

The knowledge on spatial variability of soil properties in reclaimed areas is essential for defining the actual conditions of plant growth and development (Usowicz 2001). The conditions of growth of various plants are determined by the parameters of the topsoil used for land reclamation (Bowen et al. 2005). High spatial variability of soil properties is typical of reclaimed areas and it may be affected by a great number of various factors. In practice, variability is hardly ever linear at all, therefore, interpolation methods are used that provide better opportunities to identify soil properties in respect of their defined nature of spatial variability. Such interpolation methods include the kriging method. It enables determination of the mean value of a given variable's property in any selected part of the field in question, as well as finding locations for new measurement points that will enable distribution estimation ranges to be narrowed as much as possible (Somorowski 1993). Kriging may be of a great importance in the optimization of land use and improvement of its productivity (Sigua and Hudnall 2008).

This paper provides an analysis of the areal variability of the thickness and selected physical and chemical properties of the mineral cover formed in the process of settling ponds reclamation at the former KSP "Solvay". The topsoil is intended to provide a substrate for plants, therefore, its quality is the main determinant of the development, health, and diversity of species both for herbaceous and woody vegetation.

\section{MATERIAL AND METHODS}

\section{Field and laboratory analysis}

Analysis of the topsoil that was used for the reclamation were carried out for the settling ponds Nos 21-25 (Fig. 1), 


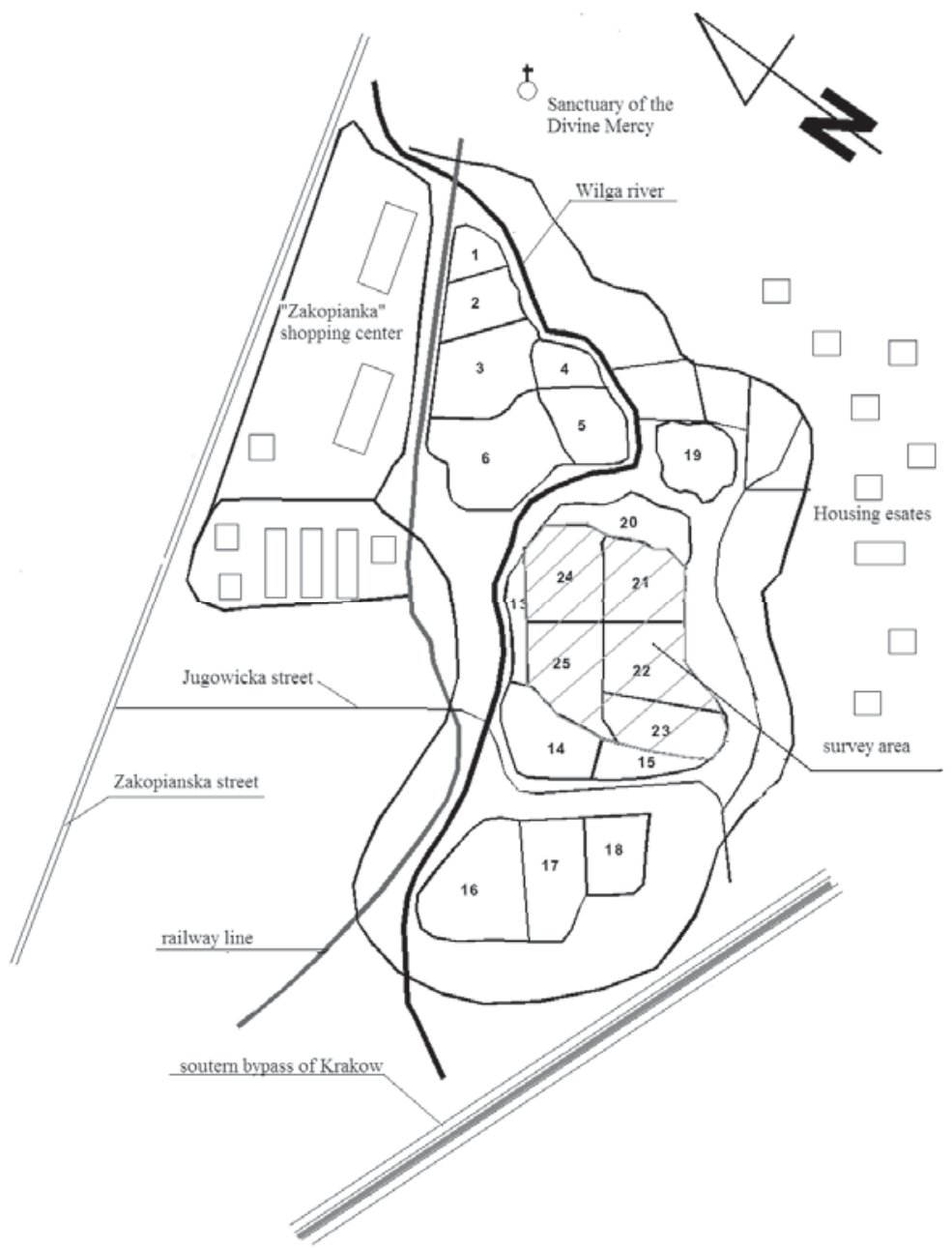

FIGURE 1. Location of soda waste settling ponds of former KSP "Solvay" Source: Zając et al. 2016.

surface area 17.43 ha $\left(\mathrm{N} 50^{\circ} 00^{\prime} 30^{\prime \prime}\right.$; E 1956'26").

A regular square network with nodes spaced every $30 \mathrm{~m}$ was outlined by GPS. This gave 132 test fields $\left(25 \mathrm{~m}^{2}\right.$ each $)$ for which the thickness of the soil cover was measured by means of a soil sampler and the soil samples were collected for laboratory analyses from the depth
$0-10 \mathrm{~cm}$. The following parameters were measured for each sample: grain-size distribution by areometry according to the industry standard BN-78/9180-11 , electrical conductivity, $\mathrm{pH}$ in $\mathrm{H}_{2} \mathrm{O}$ and $\mathrm{KCl}$ in the soil: electrolyte ratio of $1: 2.5$. Complete test results have been reported in papers by Zając (2009). 


\section{Statistical analysis}

The following measures were found for a preliminary statistic characterization of the test parameters (Hellwig 1993): maximum, minimum, median and mean values, variance, standard deviation, variation coefficient, and trend. The variability coefficient was calculated, in \%, as a measure of variance dissipation and of standard deviation in the form of a quotient of standard deviation and mean value - the variability parameters of a given parameter. The trend component was calculated by the Emerson and Wong method (after Schabenberger and Pierce 2001), according to the formula:

$$
T=\left[1-\frac{\sum[s(i, j)]^{2}}{\sum\left[Z(i, j)-z_{m}(i, j)\right]^{2}}\right]
$$

where:

$s(i, j)$ - new residual values at the point $(i, j)$,

$Z(i, j)$ - measured value of a given parameter at the point $(i, j)$,

$z_{m}(i, j)$ - median of a given parameter for all measured data in a given field.

Areal variability of the topsoil parameters was determined by kriging. The method enables the assessment of confidence intervals for the estimation, determination of the mean value of a parameter in any part of the field in question, and finding locations for new measurement points that will enable distribution confidence intervals to be narrowed as much as possible. Methodological basis for kriging was devloped by a French mathematician Georges Matheron (1963).
Speaking more precisely, kriging is a method for the optimization of the estimation of a spatially correlated parameter $Z$, both in stationary and non-stationary cases. Assuming that the value $Z_{i}=Z\left(x_{i}\right)$ is measure at the point $x_{i}(i=1,2, \ldots, n)$, the issue of point estimation consists in determination of the value $Z_{o}$ at the point $x_{o}$, where $Z$ was not measured. Changing constantly the location of the point $x_{0}$ enables determination of the entire field of variation of the variable $Z$ (Webster and Oliver 1990).

The kriging analysis was performed in two steps. In the first step, the areal correlation of distribution was described in the form of the function $\gamma$ that is referred to in geostatistics as the empirical semivariogram (Smith et al. 1994). The findings enabled a qualitative description of the regularities that are observed in the differentiation of the analyzed parameter values. The course of the empirical semivariogram was determined to have the form of points, calculated according to the equation (Oliver and Webster 1986):

$$
\gamma(h)=\frac{1}{2 m(h)} \cdot \sum_{i=1}^{m(h)}\left[Z\left(x_{i}\right)-Z\left(x_{i}+h\right)\right]^{2}
$$

where:

$\gamma(h)$ - semivariogram value for a separation distance of $h$,

$m(h)$ - number of observations, made at a separation distance of $h$,

$Z\left(x_{i}\right)$ - value, observed at a point $x_{i}$, $Z\left(x_{i}+h\right)$ - value observed at a point located at a separation distance of $h$. 
The resulting empirical semivariogram points were described by means of mathematical functions and a theoretical semivariogram was obtained. Its description requires positively definite functions, which take a zero value at the zero point. Marx and Thompson (1987) reported the following models: spherical, exponential, Gaussian, linear, and logarithmic, however, the so-called safe model functions - linear and spherical functions - are typically used (Brandyk et al. 1993, Brandyk et al. 1996). The resulting semivariogram profile indicates the type of spatial correlation of the variable of interest. There are two basic types of semivariograms. In the first type, the value of variance increases with increase in the distance of $h$ to reach a certain maximum value and is then constant even though the distance may increase. After its initial increase, the value $\gamma(h)$ reaches, for a certain distance $\alpha$ a value which is equal to the variable's variance. The distance $\alpha$ is referred to as the semivariogram's range and determines the spatial correlation limit. The variable $Z$ having this kind of semivariogram is internally stationary in addition to having secondary stationarity. In the second type of semivariograms, variance $\gamma(h)$ is a function which increases without any limits. In this case, variance is unlimited and, along with an increase in the distance $h$, it reaches a certain threshold value denoted as $C$. The threshold value is reached exactly or exclusively asymp- totically. If a semivariogram does not cross the origin of coordinates, then the so-called nugget effect, denoted as $c_{o}$ is observed. The nugget effect potentially indicates that, if a sample comprises a nugget, then other samples - including very close ones - will have different concentrations of a given component (Smith et al. 1994). All the calculations were made with the use of the specialist software: Surfer for Windows (Golden Software, 2002), Spatanal (Stein and Staritsky 1993), Statisica for Windows (StatSoft, Inc. 2014).

\section{RESULTS AND DISCISSION}

The calculated variability coefficient (Table 1) was the highest for the electrical conductivity $(\vartheta=48.93 \%)$ and the soil cover thickness $(\vartheta=44.25 \%)$. As regards particle-size distribution, average variability was typical of sand $(\vartheta=32.57 \%)$ and silt, and low variability was typical of the clay fraction $(\vartheta=$ $=18.36 \%$ ). The lowest value of the variability coefficient was found for $\mathrm{pH}$ in $\mathrm{H}_{2} \mathrm{O}$ and $\mathrm{KCl}$. The results obtained in this study are comparable with those reported for mineral soils by Warrick and Nielsen (1980) and for the mineral cover in the KSP "Solvay's" settling pond 22 (Klatka 2009). The same authors reported the lowest variability for the soil $\mathrm{pH}$, average variability for the soil particle-size distribution, and the highest aeral variability for electrical conductivity. 
TABLE 1. Statistical measures of topsoil test parameters mean values, variance, standard deviation, variation coefficient, and trend

\begin{tabular}{|l|c|c|c|c|c|c|c|c|}
\hline Topsoil parameter & $\begin{array}{c}\text { Min } \\
\text { value } \\
X_{\min }\end{array}$ & $\begin{array}{c}\text { Max } \\
\text { value } \\
X_{\max }\end{array}$ & $\begin{array}{c}\text { Median } \\
M\end{array}$ & $\begin{array}{c}\text { Mean } \\
\text { value } \\
X\end{array}$ & $\begin{array}{c}\text { Variance } \\
V(X)\end{array}$ & $\begin{array}{c}\text { Standard } \\
\text { deviation } \\
\delta(X)\end{array}$ & $\begin{array}{c}\text { Variability } \\
\text { coefficient } \\
\vartheta(\%)\end{array}$ & $\begin{array}{c}\text { Trend } \\
T \\
(\%)\end{array}$ \\
\hline Thickness (m) & 0.1 & 0.68 & 0.22 & 0.24 & 0.012 & 0.11 & 44.25 & 19.68 \\
\hline $\mathrm{pH}_{\mathrm{H}_{2} \mathrm{O}}$ & 6.75 & 7.97 & 7.64 & 7.61 & 0.03 & 0.18 & 2.42 & 29.5 \\
\hline $\mathrm{pH}_{\mathrm{KCl}}$ & 6.21 & 7.56 & 7.13 & 7.14 & 0.03 & 0.16 & 2.28 & 22.4 \\
\hline $\begin{array}{l}\text { Electrical } \\
\text { conductivity } \\
\left(\mathrm{mS} \cdot \mathrm{cm}^{-1}\right)\end{array}$ & 0.21 & 1.59 & 0.38 & 0.41 & 0.04 & 0.2 & 48.93 & 32.6 \\
\hline $\begin{array}{l}\text { Sand fraction } \\
(1.0-0.1 \mathrm{~mm})(\%)\end{array}$ & 13 & 68 & 29.7 & 27 & 93.6 & 9.67 & 32.57 & 24.6 \\
\hline $\begin{array}{l}\text { Silt fraction } \\
(0.1-0.02 \mathrm{~mm})(\%)\end{array}$ & 7 & 30 & 13.26 & 12.5 & 14.59 & 3.82 & 28.81 & 25.4 \\
\hline $\begin{array}{l}\text { Clay fraction } \\
(<0.02 \mathrm{~mm})(\%)\end{array}$ & 22 & 78 & 57.33 & 59.5 & 110.87 & 10.53 & 18.36 & 23.2 \\
\hline
\end{tabular}

A preliminary analysis of data for the respective columns of the measurement network indicated a linear dependence between average values in the respective columns and their variances; this implied the occurrence of a trend - a systematic variation (Hamlett et al. 1986). Therefore, it was assumed that the entire variance of a given soil property consists of the trend, spatial relationship, and nugget effect. Correct analysis of semivariograms requires the stationary condition to be met. Therefore, for the geostatistical analysis the trend was first removed from the data.

Using the kriging method, 17 semivariance points were found. The successive points were excluded from further calculations because they were located further than the distance between the origin of coordinates and the last measurement point (ca. $507 \mathrm{~m}$ ). The empirical semivariograms were then smoothed using a linear function and a spherical function.

The exception was the values of theoretical semivariances, obtained for $\mathrm{pH}_{\mathrm{H}_{2} \mathrm{O}}$ and $\mathrm{pH}_{\mathrm{KCl}}$ (Fig. 2) that could not be smoothed by means of such models. The values of semivariance for such properties were, essentially, in the shape of a straight line parallel to the distance axis. Therefore, neither the limit of areal correlation, nor that of the nugget effect and threshold effect was determined. Although areal correlation may exist for such parameters, its limit is lower than the distances between the measurement points $(h=30 \mathrm{~m})$.

The empirical semivariogram, as obtained for the thickness of the soil cover and the content of silt and clay fractions (Fig. 3), was smoothed using the linear model. In this case, semivariance increases with distance and it is impossible to determine the limit of areal correlation 


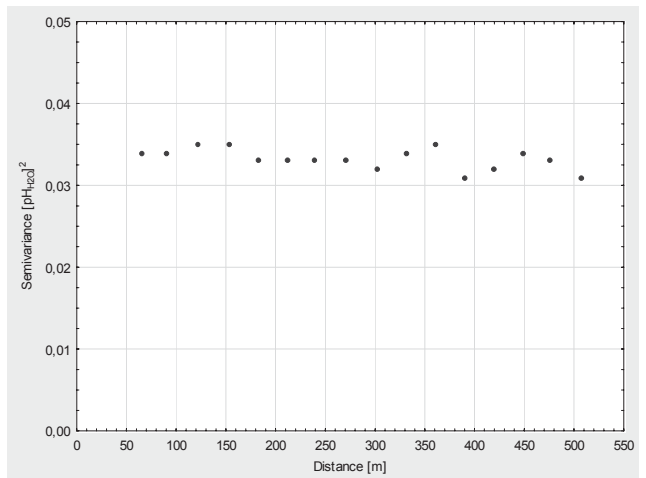

$\mathrm{pH}_{\mathrm{H}_{2} \mathrm{O}}$

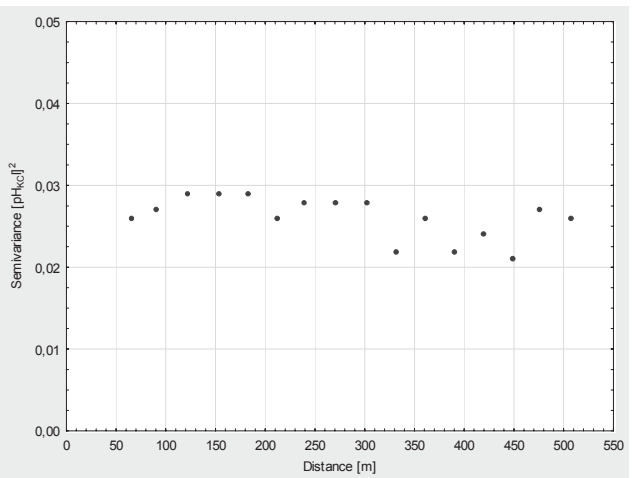

$\mathrm{pH}_{\mathrm{KCL}}$

FIGURE 2. Empirical semivariograms for $\mathrm{pH}_{\mathrm{H}_{2} \mathrm{O}}$ and $\mathrm{pH}_{\mathrm{KCl}}$

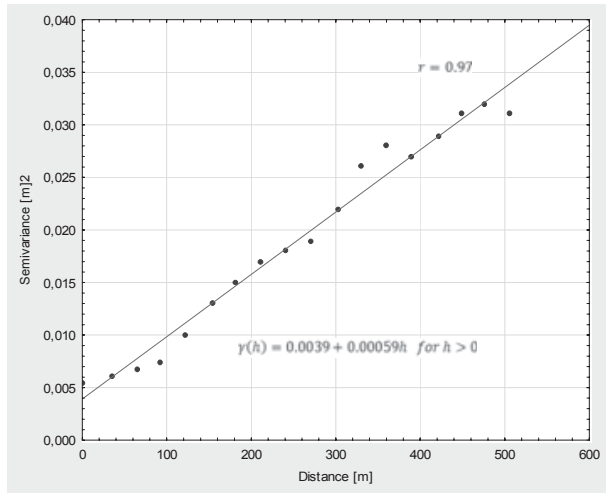

soil cover thickness

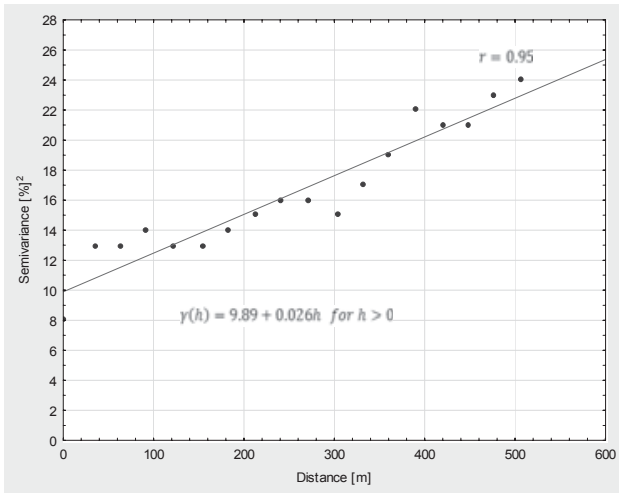

silt fraction content

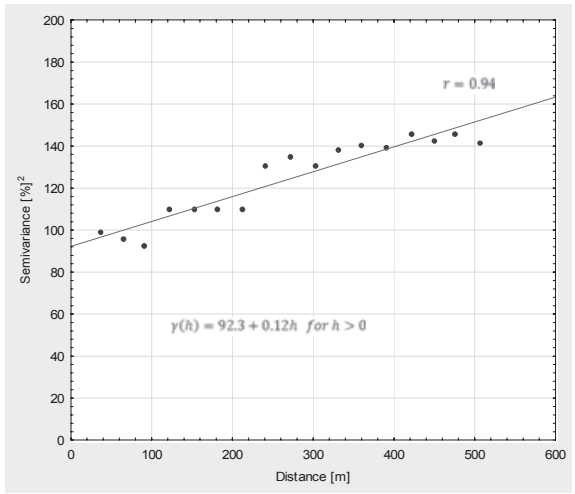

clay fraction content

FIGURE 3. Empirical and theoretical semivariograms for soil cover parameters smoothed using the linear model 
as a value for which semivariance will stabilize. On the other hand, the nugget effect was found: its values are 0.0039 , 9.89 and 92.3 , respectively.

The empirical semivariograms, plotted for the content of sand and for electrical conductivity (Fig. 4), were smoothed using the spherical model. In these cases, the nugget effect is observed which indicates that the variation of a given soil property exists at a distance smaller than

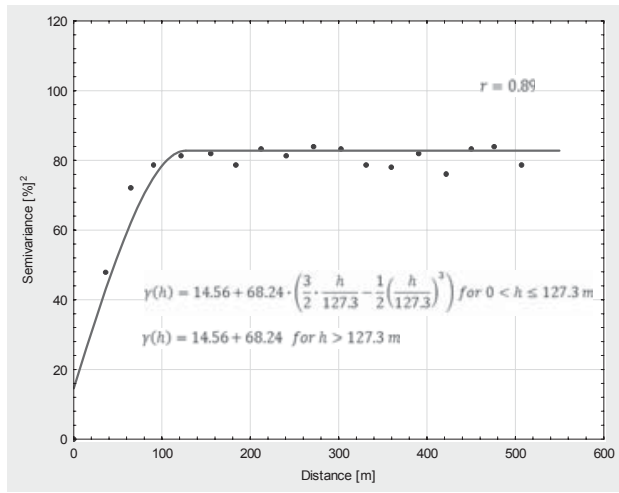

sand fraction content the spacing between the measurement points $(30 \mathrm{~m})$. The effect may depend on the accuracy of the particular measurement method used. For the semivariograms of the investigated soil properties, the limit of areal correlation was also established. The range of semivariograms for the sand fraction content and for electrical conductivity was 127.3 and $142.6 \mathrm{~m}$, respectively. Table 2 shows the list of parameters of the fitted models.

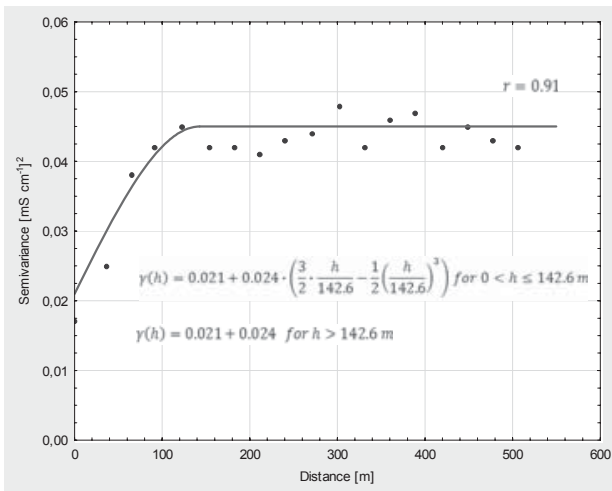

electrical conductivity

FIGURE 4. Empirical and theoretical semivariograms for soil cover parameters smoothed using the spherical model

TABLE 2. Parameters of models fitted to empirical semivariances for topsoil parameters tested

\begin{tabular}{|l|c|c|c|c|c|}
\hline Topsoil parameter & Model & $\begin{array}{c}\text { Nugget effect } \\
c_{o}\end{array}$ & $\begin{array}{c}\text { Nugget } \\
\text { effect } \\
C\end{array}$ & $\begin{array}{c}\text { Range } \\
\alpha \\
(\mathrm{m})\end{array}$ & $\begin{array}{c}\text { Correlation } \\
\text { coefficient } \\
r\end{array}$ \\
\hline Thickness $(\mathrm{m})$ & linear & 0.0039 & 0.00059 & - & 0.97 \\
\hline $\mathrm{pH}_{\mathrm{H}_{2} \mathrm{O}}$ & non & - & - & - & - \\
\hline $\mathrm{pH}_{\mathrm{KCl}}$ & non & - & - & - & - \\
\hline $\begin{array}{l}\text { Electrical conductivity } \\
\left(\mathrm{mS} \cdot \mathrm{cm}^{-1}\right)\end{array}$ & spherical & 0.021 & 0.024 & 142.6 & 0.91 \\
\hline $\begin{array}{l}\text { Sand fraction } \\
(1.0-0.1 \mathrm{~mm})(\%)\end{array}$ & spherical & 14.56 & 68.24 & 127.3 & 0.89 \\
\hline $\begin{array}{l}\text { Silt fraction } \\
(0.1-0.02 \mathrm{~mm})(\%)\end{array}$ & linear & 9.89 & 0.026 & - & 0.95 \\
\hline $\begin{array}{l}\text { Clay fraction } \\
(<0.02 \mathrm{~mm})(\%)\end{array}$ & linear & 92.3 & 0.12 & - & 0.94 \\
\hline
\end{tabular}


Using the calculated models of semivariance, maps of areal variability of the test parameters were plotted (Fig. 5) using the kriging method. The plotting of isoline was adapted to the magnitude of random error - nugget variance. High variance values provide a smoother spatial distribution in interpolation by means of the kriging method (Stach 1998).

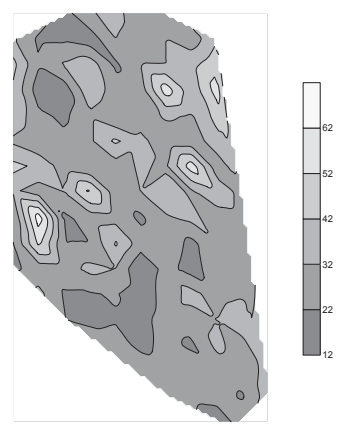

sand fraction content (\%)

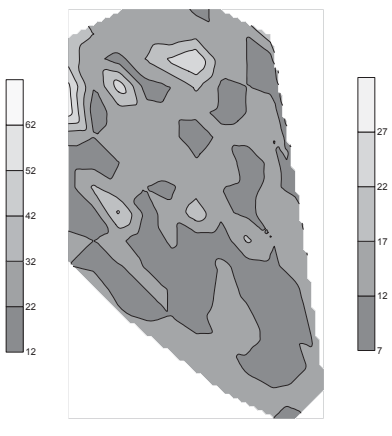

silt fraction content $(\%)$

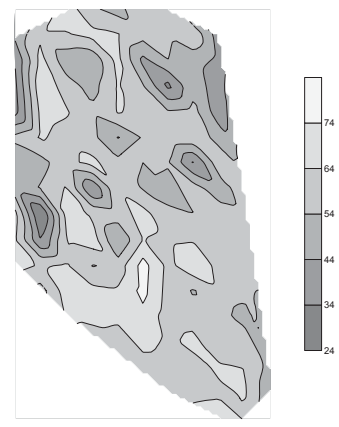

clay fraction content $(\%)$

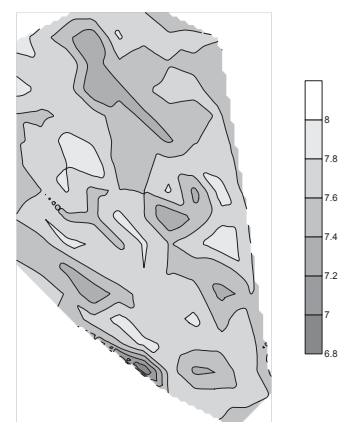

$\mathrm{pH}_{\mathrm{H}_{2} \mathrm{O}}$

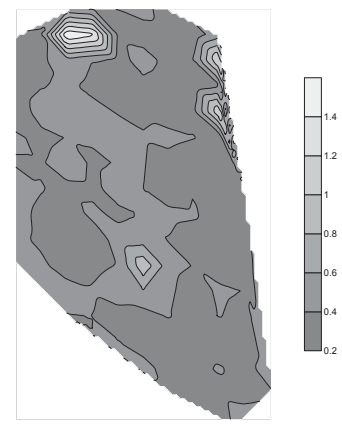

electrical conductivity $\left(\mathrm{mS} \cdot \mathrm{cm}^{-1}\right)$

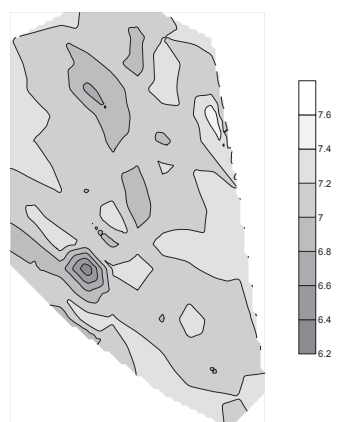

$\mathrm{pH}_{\mathrm{KCl}}$

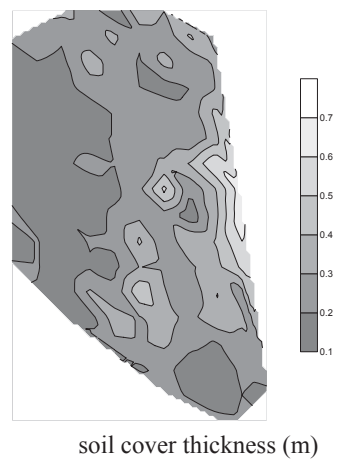

FIGURE 5. Maps of areal variability for analysed soil cover parameters 
A number of authors have studied the issue of spatial variability of the properties of mineral soils by means of the geostatistic method of kriging. Wei et al. (2006) used kriging for the assessment of spatial variability of the content of soil organic matter in the North-East China. Shao et al. (2006) used geostatistic techniques for measuring the spatial variability of soil nutrients. Keshavarzi and Sarmadian (2012) studied the variability of salinity in regions having a semi-arid climate in Qazvin province in Iran. Spatial variability of the properties of the arable layer on a lithologically heterogeneous moraine slope was determined by Stach (1998). As regards the reclaimed settling ponds holding soda waste from the former KSP "Solvay", the issue of variability of the selected soil properties for the mineral cover was studied by Klatka (2009). The findings reported by the above mentioned authors indicate that the geostatistic analysis and the resulting spatial variability maps enable an estimation of the value of a given variable at every point of the area of interest as well as determination of the mean value of this variable in any region of the area. This enables finding locations for new measurement points which narrow the distribution estimation intervals as much as possible. The results indicate that kriging is potentially a useful tool for the measurement of areal spatial variability of soils in areas reclaimed by the insulation method. The knowledge on spatial variability of the parameters of mineral topsoil, which are important for plant growth, may help improve the efficacy of biological reclamation as well as its cost-efficiency. Selecting the areas which do not satisfy conditions for the growth of vegetation provides a chance to improve selected parameters locally, an approach which is already known in precision agriculture practices.

\section{CONCLUSIONS}

A areal variability analysis of selected parameters of the mineral soil cover in the reclaimed soda waste settling ponds of the former KSP "Solvay" was performed. In the context of the envisaged direction of management of the settling ponds, the analysis showed that electrical conductivity, thickness of the soil cover and the sand fraction content have potentially the highest impact on the diversification of vegetation. Understanding the spatial variability of the soil cover parameters that are essential for vegetation, may contribute to increasing the efficiency of biological reclamation and also to cost reduction. Precise selection of the areas unsuitable for plant growth makes it possible to improve soil parameters on the limited areas similarly as in the precision agriculture.

The findings indicate that the areal variability of soil properties in the reclaimed area can be determined using the kriging method, but its reliability largely depends on the form of the empirical and the theoretical semivariogram fitted on that basis. For the studied topsoil, 
neither the theoretical semivariogram models for the $\mathrm{pH}$ in $\mathrm{H}_{2} \mathrm{O}$ and $\mathrm{KCl}$ nor the spatial correlation limit were obtained. This is because these parameters are characterized by a high randomness. For the topsoil thickness, content of silt fraction and that of the clay fraction, semivariance increased linearly with distance and it was not possible to determine the spatial correlation limit either. In the case of the electrical conductivity and the sand fraction content built empirical semivariograms were smoothed using the spherical model and also the limits of spatial correlation were established, which ranged 142.6 and $127.3 \mathrm{~m}$, respectively. Moreover, the nugget effect was observed, which may indicate that a given parameter will vary within a smaller distance than the distance between measurement points.

The maps of areal variability plotted basing on geostsatistical analysis enable the estimation of the value of the parameter in any part of the field in question, and determine its mean value at any location. The spatial dependence of the test parameters, as found in this study, indicates that the statistical assessment alone is not sufficient for their representative description, simply because of the basic assumption in statistics: independence of samples. Classical statistics is only reliable beyond the range of spatial dependence, therefore, its margin of error is potentially high within that range. The relationships, as established by the authors for the test properties, indicate that, when calculating basic statistics for a given area the nature of their areal spatial relationships ought to be taken into account.

\section{REFERENCES}

BOROŃ K., KLATKA S., RYCZEK M., LISZKA P. 2016: Kształtowanie się właściwości fizycznych, fizykochemicznych i wodnych rekultywowanego i nierekultywowanego osadnika byłych krakowskich zakładów sodowych „Solvay" [The formation of the physical, physico-chemical and water properties reclaimed and not reclaimed sediment reservoir of the former Cracow soda plant "Solvay"]. Acta Sci. Pol. Formatio Circumiectus 15 (3), 35-43.

BOROŃ K., ZAJĄC E., KLATKA S. 2000: Rekultywacja terenów składowania odpadów KZS „Solvay” w Krakowie [Reclamation of waste dump of the Krakow Soda Plant "Solvay"]. Inż Ekol. 1, 58-64 [in Polish].

BOWEN C.K., SCHUMAN G.E., OLSON R.A., INGRAM L.J. 2005: Influence of Topsoil Depth on Plant and Soil Attributes of 24-Year Old Reclaimed Mined Lands. Arid Land Res. Manag. 19, 267-284.

BRANDYK T., GNATOWSKI T., SZATYŁOWICZ J. 1996: Spatial variability of some physical properties of decomposed lowland peat soil. Proceedings of 10th International Peat Congress, Bremen. G.W. Luttig (Ed.). 2, 294-305.

BRANDYK T., SKĄPSKI K., SZATYŁOWICZ J. 1993: Zmienność przestrzenna właściwości fizycznych gleby [Spatial variability of soil physical properties]. In: Współczesne problemy melioracji. Cz. Somorowski (Ed.). Wydawnictwo SGGW, Warszawa, 140-151 [in Polish].

GWOREK B., BARAŃSKI A., KONDZIELSKI I., KUCHARSKI R., SAS-NOWOSIELSKA A., MAŁKOWSKI E., NOGAJ K., RZYCHOŃ D., WORSZTYNOWICZ A. 2004: Technologie rekultywacji gleb [Soil remediation technologies]. Instytut Ochrony Środowiska, Warszawa, 111 [in Polish]. 
HAMLETT J.M., HORTON R., CRESSIE N.A.C. 1986: Resistant and exploratory techniques for use in semivariogram analyses. Soil Sci. Soc. Am. J. 50, 868-875.

HELLWIG Z. 1993: Elementy rachunku prawdopodobieństwa i statystyki matematycznej [Elements of probability and statistical theory]. PWN, Warszawa [in Polish].

KESHAVARZI A., SARMADIAN F. 2012: Mapping of Spatial Distribution of Soil Salinity and Alkalinity in a Semi-arid Region. Ann. Warsaw Univ. of Life Sci. - SGGW, Land Reclam. 44 (1), 3-14.

KLATKA S. 2009: Analiza zmienności przestrzennej składu granulometrycznego nadkładu mineralnego na zrekultywowanym osadniku posodowym w Krakowie z wykorzystaniem metody krigingu [Analysis of spatial viriability of mineral cover texture on reclaimed post-soda waste decanter in Cracow using the kriging method]. Ochr. Śr. Zasobów Nat. 38, 131-139 [in Polish].

MAŁECKI Z. (Ed.) 1997: Restrukturyzacja - likwidacja - zagospodarowanie KZS Solvay [Restucturing - liquidation-management KSP Solvay]. In: Problemy Sozologiczne Aglomeracji Miejsko-Przemysłowych. Komitet Inżynierii Środowiska PAN, Kraków [in Polish].

MARX D.B., THOMPSON K.C. 1987: Practical aspect of agricultural Kriging. Arkansas Agricultural Experiment Station Bulletin 903.

MATHERON G. 1963: Principles of Geostatistics. Economic Geology 58, 1246-1266.

OLIVER M., WEBSTER R. 1986: Semi-variograms for modelling the spatial pattern of landform and soil properties. Earth Surf. Proc. Land. 11, 75-92.

PAŁKA J., SANECKI L. 1992: Krakowskie Zakłady Sodowe „Solvay”. Raport o stanie istniejącym [Krakow Soda Plant "Solvay". Current state report]. DDJM - Biuro Architektoniczne, Kraków [in Polish].

SCHABENBERGER O., PIERCE F. 2001: Contemporary statistical models for the plant and soil sciences. CRC Press, Boca Raton, London, New York, Washington D.C.

SIGUA G.C., HUDNALL W.H. 2008: Kriging analysis of soil properties - Implication to landscape management and productivity improvement. J. Soil Sediment 8, 193-202.

SIUTA J. 2014. Rekultywacyjna efektywność osadów ściekowych na składowisku odpadów posodowych w Janikowie [Effectiveness of reclamation of soda waste disposal site at Janikowo using sewage sludge]. Inż. Ekol. 36, 98-119 [in Polish].

SMITH J.L., HALVORSON J.J., PAPENDIC R.I. 1994: Multiple variable indicator kriging: a procedure for integrating soil quality indicators. Soil Sci. of America [Special Publication] 35, 52-80.

SHAO W.H., JI Y.J., LI P.Y., YOU L.B. 2006: Spatial Variability of Soil Nutrients and Influencing Factors in a Vegetable Production Area of Hebei Province in China. Nutr. Cycl. Agroecosyst. 75, 201-212.

SOMOROWSKI C. 1993: Współczesne problemy melioracji [Contemporary problems of melioration]. Wydawnictwo SGGW, Warszawa [in Polish].

STACH A. 1998: Zmienność przestrzenna właściwości warstwy ornej na niejednorodnym litologicznie stoku morenowym [Spatial variability of properties of the ploughed layer on a lithologically non-homogeneous morainic slope]. Bibl. Fragm. Agron. 4A, 123-142 [in Polish].

STEIN A., STARITSKY I.G. 1993: Spatanal. User's Guide. Geographic Institute RUU. The Netherlands.

Resolution LVIII/777/12 of the Krakow City Council as of 10 October 2012 concerning a local spatial development plan for "White Seas" area. Małopolska province's Official Journal of Laws of 2012, item 5214 [Uchwała LVIII/777/12 Rady Miasta Krakowa z dnia 10 października 2012 r. w sprawie uchwalenia miejscowego planu zagospodarowania przestrzennego obszaru „Białe Morza”. Dziennik Urzędowy Województwa Małopolskiego 2012, poz. 5214 [in Polish].

USOWICZ B. 2001: Ocena zmienności wybranych cech gleby przy różnym układzie i liczbie próbkowań [Evaluation of variability of soil physical properties with various number and location of measurement points]. Acta Agroph. 57, 147-158 [in Polish]. 
WARRICK A.W., NIELSEN D.R. 1980: Spatial variability of soil physical properties in the field. In: Applications of soil physics D. Hillel (Ed.). Academic Press, New York, 319-344.

WEBSTER R., OLIVER M.A. 1990: Statistical methods in soil and land resource survey. Oxford University Press, Great Britain.

WEI J.B., XIAO D.N., ZHANG X.Y., LI X.Z., LI X.Y. 2006: Spatial Variability of Soil Organic Carbon in Relation to Environmental Factors of a Typical Small Watershed in the Black Soil Region, Northeast China. Environ. Monitor Assess. 121, 597-613.

WYSOKIŃSKI L. 2009: Zasady budowy składowisk odpadów [Rules of landfill sites construction]. Instrukcje, Wytyczne, Poradniki 444, 376 [in Polish].

ZAJĄC E. 2009: Analiza właściwości fizycznych i chemicznych warstwy izolacyjnej na zrekultywowanych osadnikach posodowych byłych KZS Solvay [Analysis of physical and chemical properties of soil cover on reclaimed soda waste decanters of former KSP Solvay]. Ochr. Śr. Zasobów Nat. 38, 388-395 [in Polish].

ZAJĄC E., KLATKA S., RYCZEK M. 2007: Wpływ nadkładu glebowego na zmiany odczynu i przewodnictwa elektrolitycznego odpadów posodowych w warunkach doświadczenia modelowego [Influence of the topsoil layer on changes of reaction and electrolitic conductivity of the soda waste in model-scale experimental conditions]. Zesz. Probl. Post. Nauk Rol. PAN 520, 1, 213-219 [in Polish].

ZAJĄC E., KLATKA S., ZARZYCKI J. 2016: Distribution of woody vegetation on soda waste dumps in relation to spatial variation in selected parameters of the mineral cover. J. Ecol. Eng. 17 (5), 49-56.

ZAJĄC E., ZARZYCKI J. 2012: Revegetation of reclaimed soda waste dumps: effects of topsoil parameters. J. Elem. 17, 3, 525-536.

Streszczenie: Zmienność przestrzenna warstwy izolacyjnej na zrekultywowanym sktadowisku odpadów posodowych. W pracy dokonano analizy zmienności przestrzennej miąższości oraz wybranych właściwości fizycznych i chemicznych warstwy mineralnej ukształtowanej w procesie rekultywacji stawów osadowych byłych Krakowskich Zakładów Sodowych „Solvay”. Jako że warstwa ta ma stanowić podłoże dla roślinności, jej jakość jest głównym czynnikiem decydującym o rozwoju, kondycji zdrowotnej oraz różnorodności gatunkowej zarówno roślinności zielnej, jak i drzewiastej. Zmienność przestrzenną parametrów nadkładu glebowego wyznaczono metodą krigingu. W kontekście planowanego kierunku zagospodarowania zrekultywowanych osadników posodowych byłych KZS „Solvay” wykonana analiza zmienności przestrzennej wybranych parametrów mineralnej warstwy izolacyjnej wykazała, że potencjalnie największy wpływ na zróżnicowanie roślinności mogą mieć przewodność elektryczna, miąższość nadkładu glebowego oraz zawartość frakcji piasku. Poznanie przestrzennego zróżnicowania parametrów nadkładu mineralnego, istotnych z punktu widzenia wegetacji roślin, może przyczynić się do zwiększenia efektywności rekultywacji biologicznej i ograniczenia kosztów. Wytypowanie powierzchni niespełniających warunków wzrostu roślin daje możliwość miejscowej poprawy wybranych parametrów, analogicznie do metod stosowanych w rolnictwie precyzyjnym.

\section{MS received January 2017}

\section{Authors' addresses:}

Sławomir Klatka, Ewelina Zając

Katedra Melioracji i Kształtowania Środowiska Uniwersytet Rolniczy w Krakowie

al. Mickiewicza 24/28

30-059 Kraków

e-mail:rmklatka@cyf-kr.edu.pl e.zajac@ur.krakow.pl

Jan Zarzycki

Katedra Ekologii, Klimatologii i Ochrony

Powietrza

Uniwersytet Rolniczy w Krakowie

al. Mickiewicza 24/28

30-059 Kraków

e-mail: j.zarzycki@ur.krakow.pl 